\title{
Interpreting the stones: Turku Castle as narrative space
}

Petja Aarnipuu*

\begin{abstract}
The history of nationally important heritage sites is often represented as a rather straightforward process of chronological evolution. At Turku Castle in Finland, this narrative is literally set in stone in the restoration works between the late 19th and mid 20th century. These restoration processes resulted in spatial anachronisms, but the architectural decisions also facilitate the visitors' experience of time and place at the castle. I am introducing new approaches from the fields of narrative and spatial theory, which can be applied in the analysis of the diverse and intertwining relationships of the past and the present in museal representations. The Turku Castle case proves that "inauthenticity" need not become a stumbling block.
\end{abstract}

Key words: Heritage, narrative, space.

It is commonly agreed that the walls of an old building are silent, no matter how much we might wish them to speak. As a folklorist, I have chosen to take a theoretical standpoint that goes somewhat against this common-sense approach. At the monumental and museal castle of Turku (Äbo in Swedish), even the stone walls are a method of communication. The castle can be analysed as if it were a narrative or a set of narratives - a narrative space. The castle itself reflects an emplotment of the past in the narratives of its restorers and of the tour guides.

My starting point is simple: it is the understanding that a building in an urban environment is - and has always been - a product of human enterprise, creativity and ambition.
This is obvious to the point of being naïve, and yet the underlying artificial nature of all tangible heritage is a fact that is often forgotten or ignored - in tourist-related contexts, for example. An old building can be perceived as having "always" been there, or at least having evolved steadily, and almost by itself, through the centuries, while having remained essentially the same.

Everyone with a more professional interest in cultural heritage knows, of course, that every very old building has most probably gone through many modifications and reparations, as well as changes in form and in function. Turku Castle is also the result of careful planning, building, re-building and restoration work. In the course of its seven centuries of 


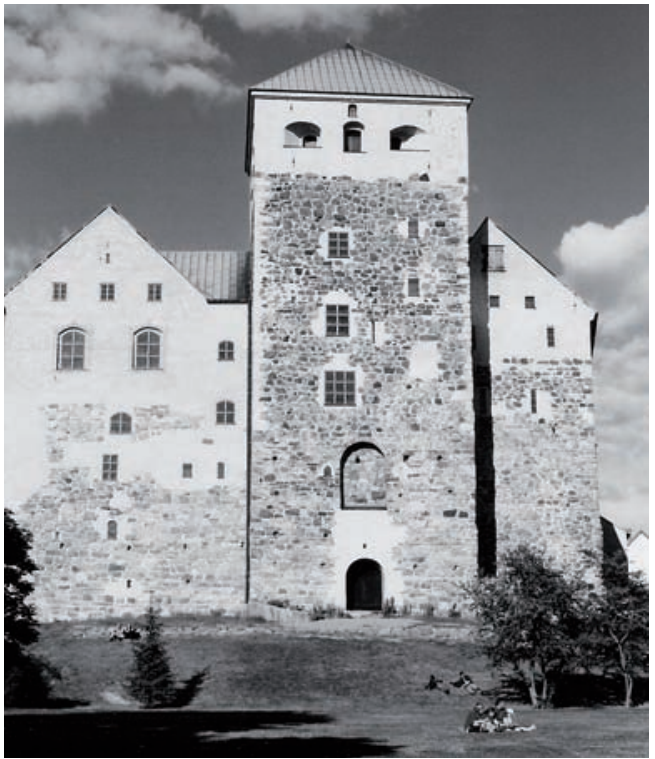

The western façade of Turku Caste has become an iconic view, central to the imagery of Turku as a city with history. Photo Petja Aarnipuu 2003.

existence, Turku Castle has changed from a medieval defensive structure into a Renaissance palace and from a late-19th century derelict jailhouse into a prime example of the medieval built heritage in Finland.

\section{The eRAs of TuRku CAstle}

The construction of Turku Castle can be described via chronology, as it is usually done in historical accounts, from one century to anot141 her. For the purposes of my own research (Aarnipuu 2008), however, I have chosen to approach and present the castle's past as eras. In the diagram below, I have depicted the castle's history as two sets of more descriptive eras around the chronological continuum.

The founding date of the castle is not known, but it is thought that the building process began in the 1280 s. In medieval times, it was an important stronghold and a military base under Swedish rule. Its most celebrated days of glory were in the 1560 s, when Duke Johan, encouraged by his father King Gustavus Wasa, took to enhancing the by then oldfashioned medieval fortress into a Renaissance palace. In 1614, however, the old part of the castle was once again badly burnt. Unlike in the earlier centuries, it was not properly repaired. What administrative functions that were left at the castle were transferred into the bailey. In the 1760s, the castle looked well beyond repair, as described by Rev. Eric Lennqvist, who worked there as the chaplain for the prisoners. He did not expect the castle to have much of a future, if any at all. The turn towards a more positive future came in the late 19th century when the new Historical Museum of Turku moved in, first acquiring only a couple of rooms for its functions, then

Figure 1: From a defensive structure to cultural heritage

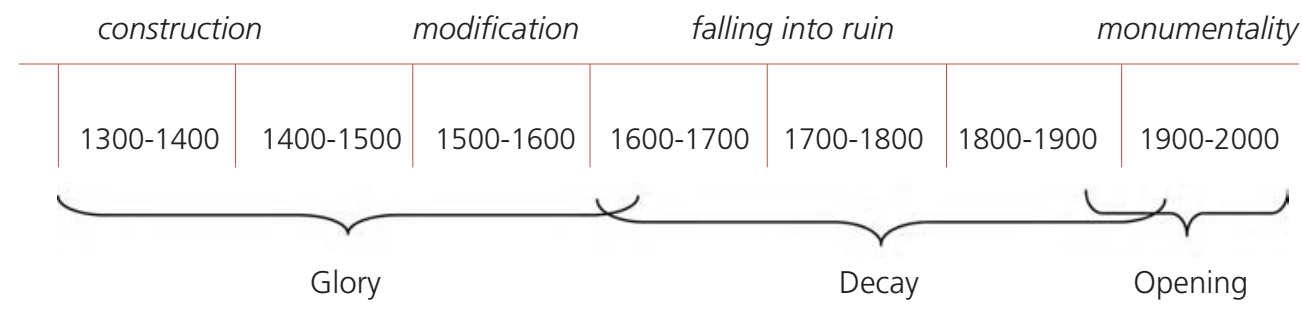




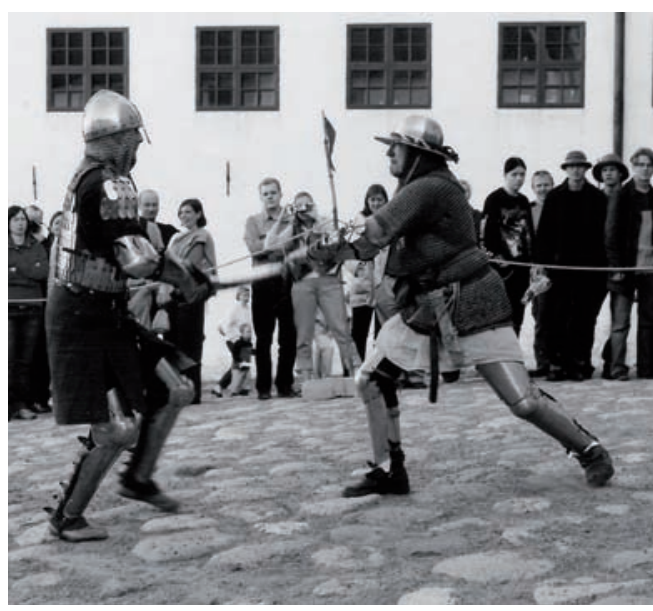

Mimetic reconnection with the past at the castle yard. Photo Petja Aarnipun 2003.

gradually the whole bailey. (Gardberg 1959; Lennqvist 1885.)

In the late 1930s, the functionalist architect Erik Bryggman was appointed to the task of restoring the old main part of Turku Castle. As if to complete the destruction, however, the castle was hit in the Russian bombings of the early days of the Continuation War in 1941. The main castle was practically gutted. What was left of it stood without proper roofing for the duration of the war (Gardberg $1961,17)$. In 1944, the second plan for the restoration of Turku Castle, Förslaget till restaurering av Abo slot was published (Bryggman \& Cleve 1944).

\section{THE MODERN MEDIEVAL CASTLE}

The writers of the restoration plan of 1944 , architect Erik Bryggman and museum intendant Nils Cleve, outlined a castle that is medieval in form, but modern in function. The
Förslaget till restaurering av Abo slott restoration plan presents (and predicts) Turku Castle as a castle opened up for visitors. The plans include museal use in a larger scale, and venues for the City of Turku's official celebrations. While the architectural, historical, and art historical features were to be respected and restored, some major renovations and new constructions had to be made to achieve this renewed functionality. There were to be modern facilities for the people who come to the castle and for those who cater for these visitors. The facilities in question were to be partly hidden in the structures, but some large areas would also be fully visible and modern in style. These would include the downstairs entrance hall, complete with the cashier's desk and a separate lobby for coat racks and washrooms, and the completely new exhibition hall in the attic. (Bryggman \& Cleve 1944: 2).

In my view, the two aims outlined in the restoration plan, monumentality and functionality, point towards one goal: Turku Castle was to become a heritage site. Compared to what we know about the castle in medieval times, the most drastic spatial difference, as proposed in the Förslaget till restaurering av Abo slott plan, is that it is possible to complete a full circle inside the restored main castle. The medieval castle was built for defence, and the living suites could be closed off separately. There could not be doors to connect all the rooms. Later, the new warfare technology was reflected in architecture as well, and also in Duke Johan's Renaissance palace, which is built above the then old-fashioned medieval quarters, rooms were generally linked to the next one by a doorway. According to the 1944 plan, this practice was to be continued into the medieval parts as well, for the benefit of visitors. Bryggman and Cleve even present a suggestion for 
the route of the guided tour round the castle. To accommodate all this, quite a few new stairs and doorways had to be inserted in and between the medieval inner walls. The medieval rooms were restored in their medieval places, even to the point of anachronistically over-ruling the chronologically later changes. (Bryggman \& Cleve 1944: 3; Gardberg 1961.)

At a heritage site, the visitors have to be able both to recognize and experience the historical and art-historical values at the castle. This is why, for the first time in the architectural history of Turku Castle, the Medieval, the Renaissance, the Modern, and the Present as architecturally constructed or reconstructed spaces, can all be visited within the same hour. Instead of experiencing the inconveniently closed medieval spaces, the visitors can now wander straight through them and experience temporality via other architectural details, like ceilings. The historical inconvenience can still be experienced while climbing the hundreds of steps up and down between the different spaces. But even that is optional. As the Turku Castle of today is not only a monument of history but also a venue for modern functions, there is also a lift.

\section{NARRATIVE SPACE}

Considering all the changes, reconstructions, and modern technology used in bringing Turku Castle "alive" once more (c.f. Gardberg 1961), one of the cornerstones of Finland's tangible heritage could even be deemed anachronistic or inauthentic. The objective of my study, however, is to see it in a wider context of heritage as communication with the past from the present. The past is irreversibly gone, and all we know about it is necessarily, to some extent, an interpretation of traces (Tuo- minen 2001). It is therefore important not to 143 stumble on anachronisms and inauthenticities in the representations of the past, but to find a new reading of them.

To achieve this new reading of Turku Castle, I have been studying it firstly as space, described by Michel de Certeau as "a practiced place" (de Certeau 2002: 117). Secondly, I am approaching the numerous narrative aspects of the castle, following Paul Ricoeur's analysis of narrative as a threefold mimetic process (Ricoeur 1990).

In de Certeau's analysis, 'place' is the "instantaneous configuration of positions". In places, things exist simultaneously and in relation to other things. Compared to the relative stability of a place, 'space' is more like a happening: it comprises place, time and actions of the people present. (De Certeau 2002, 117.) In my study, I find it is essential to consider 'space' in relation to the representations of time and temporality in the place - Turku Castle. This castle, as an example of built heritage, can be seen either as a point of reference on a temporal map, or as a map of time in itself. For an individual visitor to the castle, the castle space depends greatly on the ways in which different eras and moments in history are represented there. Through his/her visit, the visitor transforms the castle as a 'place' into a "practiced place" - space. Space, therefore, is a fleeting moment in time, lived by a person in a place, but it is in relation to other fleeting moments lived in the same place by other people.

By applying the theoretical aspects of narrativity in the analysis of Turku Castle, I am opening another angle from which I am interpreting the castle as a space. My analytical key to the various narrative relationships that take place at a monumental and museal site such as 
144 Turku Castle, is the threefold mimetic process of pre-figuration, con-figuration and re-figuration, inspired by the writings of Paul Ricoeur (1990).

Mimesis in its basic meaning is the same as imitation, especially in reference to the artistic representation of reality, but also in reference to social emulation, and to adaptation according to the circumstances. On the other hand, mimesis is closely linked with learning by imitation. (Gebauer \& Wulf 1995, 1-8, 53-54.) Architecture is certainly a mimetic art: it is difficult even to imagine a building with no reference at all to some other, previous buildings. Restoration architecture is all the more so, as a new part is purposefully constructed to resemble, even to represent, a part that either exists as a fragment or has long ago ceased to exist. In the latter case, the word "reconstruction" is used instead of "restoration". Education and learning are nowadays central in museums, and in my analysis, mimetic ways of teaching and learning are very much applied in many forms of museal work. It is important to see mimesis as more than just copying or reproducing something. Mimetic process is creative imitation, it produces something new. (Ricoeur 1990: 45; Gebauer \& Wulf 1995: 2-5.)

In the mimetic process of narration, what takes place between the preliminary understanding of the world (pre-figuration) and of some new way of understanding it (re-figuration) is emplotment (Ricoeur 1990: 54-70). Action, temporality and characters are arranged according to a narrative plot. Combining the theoretical starting points of 'space' and 'narrative', I am approaching the castle as if it were a narrative (or an evolving set of narratives), narrated in space but also through space.

I have employed the idea of creative imita- tion in - for example - the analysis of the guided tours at the castle, or of the restoration processes that took place there between the late-19th and mid-20th centuries. Seeing things like the restoration teams of the mid20 th century and the present day tour guides as creative narrators, I am looking beyond the dilemma of the anachronistic spaces. What transpires is an inter-connected web of texts and spaces, tangible and intangible narratives. In my interpretation, it is through this multidimensional narrativity that the guidelines are set for understanding and experiencing the place (Turku Castle) as temporal. Turku Castle is a constructed building and, as such, a mimetic narrative of the past.

\section{GUIDED TOURS TO MULTIPLE PASTS}

In the course of architectural, literary, and oral emplotment, all of which interact with each other, some eras are accentuated while others are left to one side or forgotten. As can be seen from the visualisation in Figure 1, the days of glory and those of decay were almost as long. The monumental architecture of the contemporary Turku Castle conveys the narrative of power, growth and prosperity during two chosen eras, the Middle Ages and the Renaissance. The era of decay (which I propose be recognised) is not included in this architectural emplotment of the past, which is produced by the restorers of the castle.

Nowadays, however, it is the Turku Provincial Museum that holds the narrative power over Turku Castle. The majority of the guided tours available at Turku Castle take place in the older part, or the main castle, according to the plans first outlined already in the 1944 restoration plan (Bryggman \& Cleve 1944). On the tour, the guides provide the spatial and 
temporal "map" of the castle by walking the tour with the visitors and by putting into words what the architecture already tells in structures and forms. In the guides' emplotment of the time and place in the castle, there are also anecdotes about the historically important or historically interesting people who have inhabited the place. The emphasis is on the medieval and Renaissance structures.

The stone walls are not flexible, and the variation of the routes is therefore spatially limited. In contrast, the great power of oral narrative is that with a different emplotment, the guides can create diversity in the ways in which the past is seen. To a great extent, the historical narrative substance is set according to the lines laid down in the restoration processes and in the literature, especially by the historian and museum professional of many trades, C. J. Gardberg. But seeing the wealth of different tour themes, it is also clear that the past can also be seen as a pool of endless possibilities to emplot place, time and action into a narrative space. For example, the restored castle in itself commemorates the monarchs and the days of glory. On the tours, the servants, guards and prisoners can also be taken into account. They are nameless in the history of Turku Castle but essential parts of the castle's day-to-day life in past realities extending over centuries, in the days of glory as well as of ruin.

Narrative emplotment is about making choices, about inclusion and exclusion in order to communicate meanings. In the narrative space, one emplotment does not exclude other possible emplotments. In a place of cultural heritage like Turku Castle, which is restored in order to store and express knowledge about history, the architectural structures are monumental narration. Narratives that are complimentary or contradictory to this beco145 me possible - during guided tours, for example. What is set in stone at Turku Castle gives both historical substance and a stage for experiencing the continuum and discontinuations in time. The most flexible and humane way of conveying the sense of past and the details of history, however, is a dedicated guide. The totality of past - all of the simultaneous truths and experiences lived at one place in different times - can never be reached, but if "time travel" is being sought after, that great feat of imagination is best achieved through diversity in spatial narration.

\section{NOTER}

1. "Built heritage" was changed to "building heritage" in the process of proof reading, but I think built heritage would be the right concept here.

\section{REFERENCES}

Aarnipuu, Petja: Turun linna kerrottuna ja kertovana tilana. Suomalaisen Kirjallisuuden Seura: Helsinki 2008. (A doctoral dissertation.)

Bryggman, Erik \& Cleve, Nils: Förslaget till restaurering av Abo slott. Finska Litteratursällskapet: Helsinki 1944.

Certeau, Michel de 2002: The Practice of Everyday Life. Translated by Steven Rendall. University of California Press: Berkeley 1984/2002.

Gardberg, C. J.: Abo slott under den äldre vasatiden. En byggnadshistorisk undersökning. Finska fornminnesföreningens tidskrift 60. Finska fornminnesförening: Helsinki 1959.

Gardberg, C. J.: A Abo slott och dess restaurering. Åbo stadt: Åbo 1961.

Gebauer, Gunter \& Wulf, Christopher: Mimesis. Cul- 
ture - Art-Society. Translated by Don Reneau. University of California Press: Berkeley 1992/1995.

Lennqvist, Eric: "Historisk Afhandling om Åbo Slott." - Bidrag till kännedomen af vårt land, samlade och utgifna af K. G. Leinberg, Professor. Vol. 1. J. Länkeläs förlag: Jyväskylä 1885.

Ricoeur, Paul: Time and Narrative. Vol 1. Translated by Kathleen Blamey \& David Pellauer. The University of Chigaco Press: Chigaco and London 1990.

Tuominen, Laura: "Arvot ja arvottaminen." - Rakennusperintömme. Kulttuuriympäristön lukukirja. Eds. Irma Lounatvuori and Lauri Putkonen. Ympäristöministeriö ja Museovirasto: 2001

* Petja Aarnipuu, PhD, is a recent alumnus of the University of Helsinki Institute of Cultural Studies, folklore.

Address: Tyrvännöntie 1228, FI-14620 Tyrväntö

E-mail:petja.aarnipun@helsinki.fi
Aarnipuu, Petja: Turun linna kerrottuna ja kertovana tilana (The Turku Castle: Cultural Heritage as Narrative Space). Suomalaisen Kirjallisuuden Seuran toimituksia 1162. ISSN: 0355-1768. Diss. 252 s. Ill. Helsinki 2008. English summary.

Redan i rubriken till sin doktorsavhandling anger Petja Arnipuu att han studerar ett historiskt monument, Åbo slott, ur olika aspekter. Dels är det frågan om restaureringstänkandets utveckling och dess inflytande på byggnader vi uppfattar som historiska och dels att historien konstrueras genom en serie valsituationer både i byggnads- och restaureringskedet samt i nutiden, när det monumentala byggnadsverket presenteras för besökarna på Åbo slott. I sin tolkning av de olika valsituationerna stöder sig författaren bl.a. på hermeneutikern Paul Ricoeurs postnarratologiska tolkning av den hermeneutiska cirkeln. På en generell nivå tycks Aarnipuu ha formulerat forskningsproblematiken som 1) hur ter sig historien för oss och 2) hur konstrueras tidslighet som en del av våra kulturminnesmärken?

Fastän Åbo slott är ett av de äldsta slotten i Finland och det har haft stor betydelse i synnerhet under medeltiden och 1500-talet har endast ett fătal undersökningar gjorts om det. Redan på 1800-talet togs de första initiativen till ett historieverk om slottets historia i sin helhet, men det första vetenskapliga verket om slottet är C. J. Gardbergs byggnadshistoriska doktorsavhandling Abo slott under den äldre vasatiden, publicerad 1959. Den kompletteras av Kari Uotilas byggnadsarkeologiska doktorsavhandling från 1994 och Johanna Helenius' avhandling om mathushållningen på Åbo slott 15561568, publicerad två år tidigare. Dessutom behandlas slottet kortfattat i olika historiska verk och artiklar. 